\title{
Students' perception of the advantages and disadvantages of learning English for biology with native and non-native English- speaking teachers
}

\author{
Pham Cu Thien ${ }^{1 *}$, Tran Thi Thanh Tuyen ${ }^{1}$, Huynh Cong Minh Hung ${ }^{2}$ \\ ${ }^{1}$ Ho Chi Minh City University of Education, Vietnam \\ ${ }^{2}$ Ho Chi Minh City Open University, Vietnam \\ *Corresponding author: thienpc@ hcmue.edu.vn
}

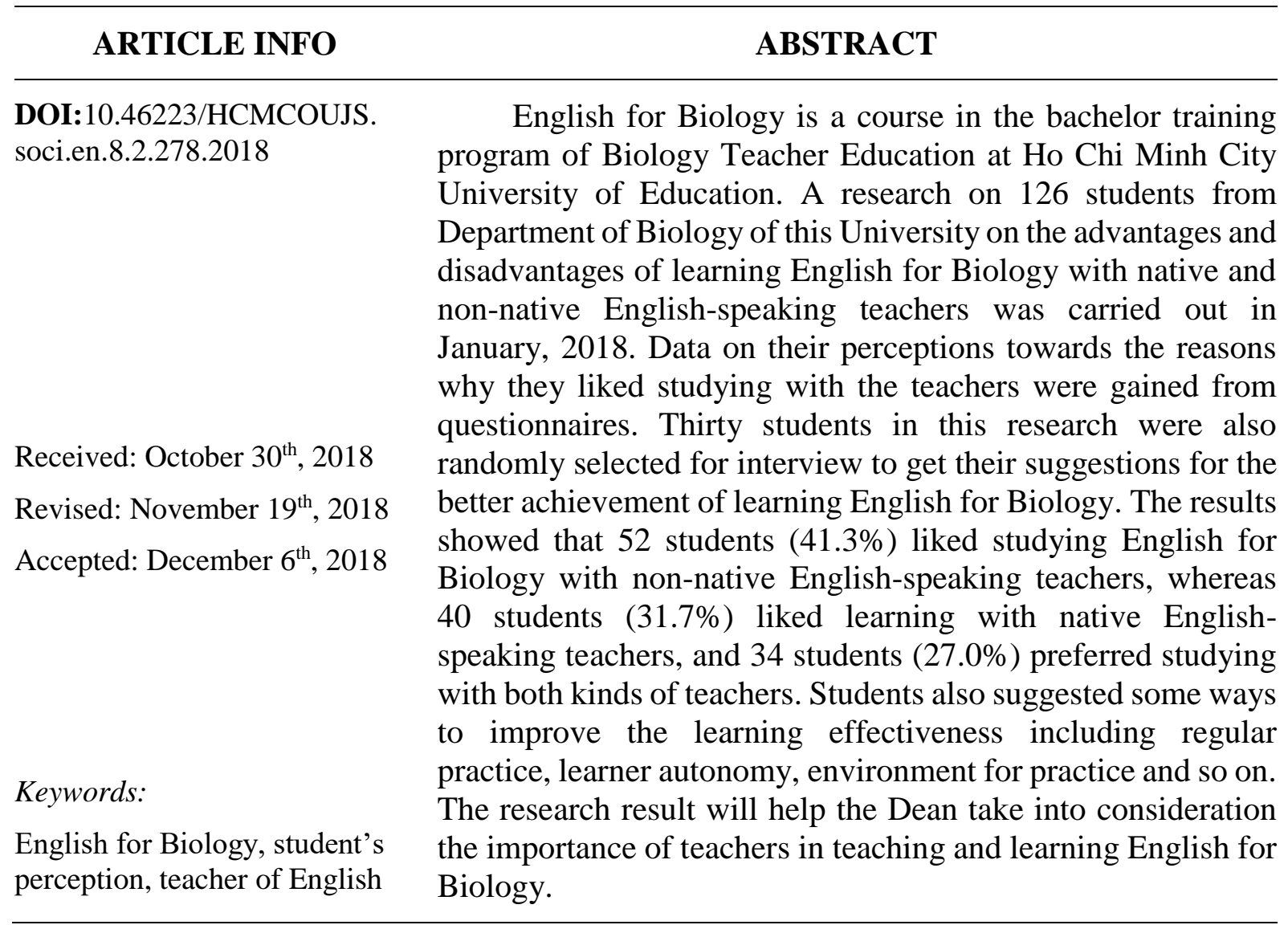

\section{Introduction}

English for Biology is a course in the bachelor training program of Biology Teacher Education at Ho Chi Minh City University of Education. This new course will be taught to students from batch 42 in 2019 at this university. The effectiveness of learning this course is very essential for students because they will use this skill to read English documents in the biology field, teach students at high school or secondary school, research and work in the international environment. Besides the training program of the University, teaching facilities, time of teaching and so on, teacher is very important. There are two main kinds of teachers for this course: native and non-native English-speaking teachers. The term "non-native speaker" is often defined in contrast to the "native speaker" of a language (Luk \& Lin, 2007). The native English-speaking teachers have played a key contribution to English language learning and 
teaching across the globe (Albakrawi, 2014). However, the number of non-native Englishspeaking teachers has been increasing and exceeds that of native English-speaking teachers in the world (Ma, 2012), the estimation is that up to 80\% of English teachers are non-native English-speaking teachers (Rechardson, 2016). Medgyes (1994) stated that different teachers have different strengths and weaknesses, and teachers' ability depends on how students view individual teachers. The question is that the students in Department of Biology at Ho Chi Minh City University of Education prefer studying English for Biology with a native or non-native English-speaking teacher? What kinds of teachers do students like to learn this course with? Therefore, research on students' perception of the advantages and disadvantages of learning English for Biology with native and non-native English-speaking teachers at the Department of Biology was carried out.

\section{Literature}

There have been many studies on learners' perception of the advantages and disadvantages of learning English with different kinds of teachers. Pham and Huynh (2018) researched on the perception of 26 master students major in English about the advantages and disadvantages of studying pronunciation and speaking with foreign teachers. Most of them preferred studying with teachers from the United States of American, and the most popular reason was that teachers could use English more accurately. Walkinshaw and Duong (2014) studied 50 Japanese and 50 Vietnamese university students about their perception of studying English with native and non-native English-speaking teachers. Both groups showed their advantages and disadvantages of teaching English. This research found that non-native Englishspeaking teachers were better explaining grammar and classroom interaction, while the other was good at pronunciation, language use and culture. Walkinshaw and Duong (2012) carried out research on 50 third year English major students in two universities in Vietnam about their preference to studying English with native and non-native English-speaking teachers. The result showed that English competence was the one which the respondents chose for the native English-speaking teacher, all other qualities such as teaching experience, qualifications, friendliness, enthusiasm, the ability to deliver interesting and informative classes were valued for both groups of teachers. Ma (2012) studied on the differences in "perceived teaching behavior of native and non-native English -peaking teachers in Hong Kong", the findings showed the differences in teaching approaches, teaching objectives and classroom atmosphere. Xiaoru (2008) studied 75 university students majoring in English and got the results that each kind of teachers had their own strengths and weaknesses, so they should complement each other when teaching English. Madrid and Canado (2004) researched "Teacher and student preferences of native and non-native foreign English teachers", the results showed that the students' preferences for native teachers increased with academic level. Lasagabaster and Sierra (2002) researched 76 university students, in which there were 38 students majoring in English. The results were that they liked studying with English-speaking teachers of the combination of both groups.

A dissertation by Tsou (2013) researched Taiwanese University students' perception toward native and non-native English-speaking teachers. There were 184 non-English major students who answered the questionnaires in this study. Their perception was that both groups had their strengths and weaknesses in English instruction. The disadvantages of this group were the advantages of the other groups in terms of English proficiency, communication and the 
solution for students' problems. Alseweed (2012) studied in Qassim University with 169 Saudi male university students (non-English major) to get their perception when studying English in the classroom with native and non-native English-speaking teachers. The results showed that they like studying with native English teachers, especially in the higher level. However, they also showed their interest in studying with non-native English speakers because of their providing a serious learning environment and clear answers to students' questions. Clouet (2006) said that each teacher had different advantages and the same class should have both native and non-native teachers so that the students could get better knowledge.

The above information mentioned a lot about the advantages and disadvantages of studying English with native and non-native English-speaking teachers. However, there was no research on the perception of biological students in Ho Chi Minh City University of Education. This research will find their perceptions of learning English for Biology with native and non-native English-speaking teachers so that the Dean can take into consideration the importance of teachers in teaching this course.

\section{Research questions}

Research question 1: What are the perceptions of biological students at Ho Chi Minh City University of Education about the advantages and disadvantages of studying English for Biology with native and non-native English-speaking teachers?

Research question 2: What are their suggestions for students to study English for Biology more effectively?

\section{The study}

\subsection{Settings and participants}

Ho Chi Minh City University of Education is a state university that has a training program for students who majored in Biology Teacher Education. This university enrolls students once a year, so there are usually four batches in January, 2018 including batches 40, 41, 42 and 43, and all of the students who had experiences working with foreign English speakers participated in the study.

\subsection{Data collection}

One cross-sectional survey was done to collect data by using the questionnaire and interview at one point of the time in January, 2018. All the students (100\%) who had experiences working with foreign English speakers in Department of Biology in Ho Chi Minh City University of Education filled in the questionnaire at the classroom of the school. The list of students was obtained with the help of the two administrators in Department of Biology. The questionnaire was written in Vietnamese to prevent from misunderstanding, then it was translated into English later for the paper. After the questionnaire was designed, it was showed to two experts on TESOL teaching for comments. After revision, the questionnaire was tested by ten testers to know whether they could understand or not, also to be sure that the questionnaire was good enough. The unclear questions were explained directly to the participants. Thirty students in this research were also randomly selected for interviews to get their suggestions for the better achievement of learning English for Biology. 


\subsection{Data analysis}

Microsoft Office Excel and SPSS software (Statistical Package for Social Sciences version 20; SPSS Inc., Chicago, Illinois) were used for data entry and statistical analysis. Double entry was done to prevent from errors. Descriptive analysis, mainly the percentage was used for data analysis. Cronbach's Alpha was calculated to determine the reliability of data from the questionnaire. In this study, the alpha was 0.787>0.700, and it means that the items are reliable (Fraenkel \& Wallen, 2009). The mean scores in this research were calculated with the range from 1 (completely disagree), 2 (disagree), 3 (neutral), 4 (agree) to 5 (completely agree).

\section{Results}

\subsection{Participants' information}

There were 126 students from Department of Biology, Ho Chi Minh City University of Education who had experience working with English speakers who joined the research. In which, $20.6 \%$ of students were in the fourth year, $29.4 \%$ of them were in the third year, $32.5 \%$ were in the second year, and the rest of $17.5 \%$ were in the first year (Table 1).

\section{Table 1}

Percentage of students in each batch participated in the research $(\mathrm{N}=126)$

\begin{tabular}{|c|l|c|c|}
\hline No & Batch/ Year & N & Percentage (\%) \\
\hline 1 & 40 (Senior students) & 26 & 20.6 \\
\hline 2 & 41 (Junior students) & 37 & 29.4 \\
\hline 3 & 42 (Sophomore) & 41 & 32.5 \\
\hline 4 & 43 (Freshman) & 22 & 17.5 \\
\hline \multicolumn{2}{r|}{ Total } & 126 & 100 \\
\hline
\end{tabular}

Source: The researcher's data analysis

\subsection{Percentage of students already worked with foreign English speakers $(N=126)$}

All of the students had a chance of working with foreign English speakers from 18 countries. Most of them were from the United States of America (50.8\%), England (47.6\%), Australia (31.0\%) and the Philippines (11.9\%). The others with lower percentages were from South Korea, India, Singapore, China, Canada, France, Japan, New Zealand, the Netherlands, Spain, Belgium, Germany, Russia and Brazil (Figure 1). 


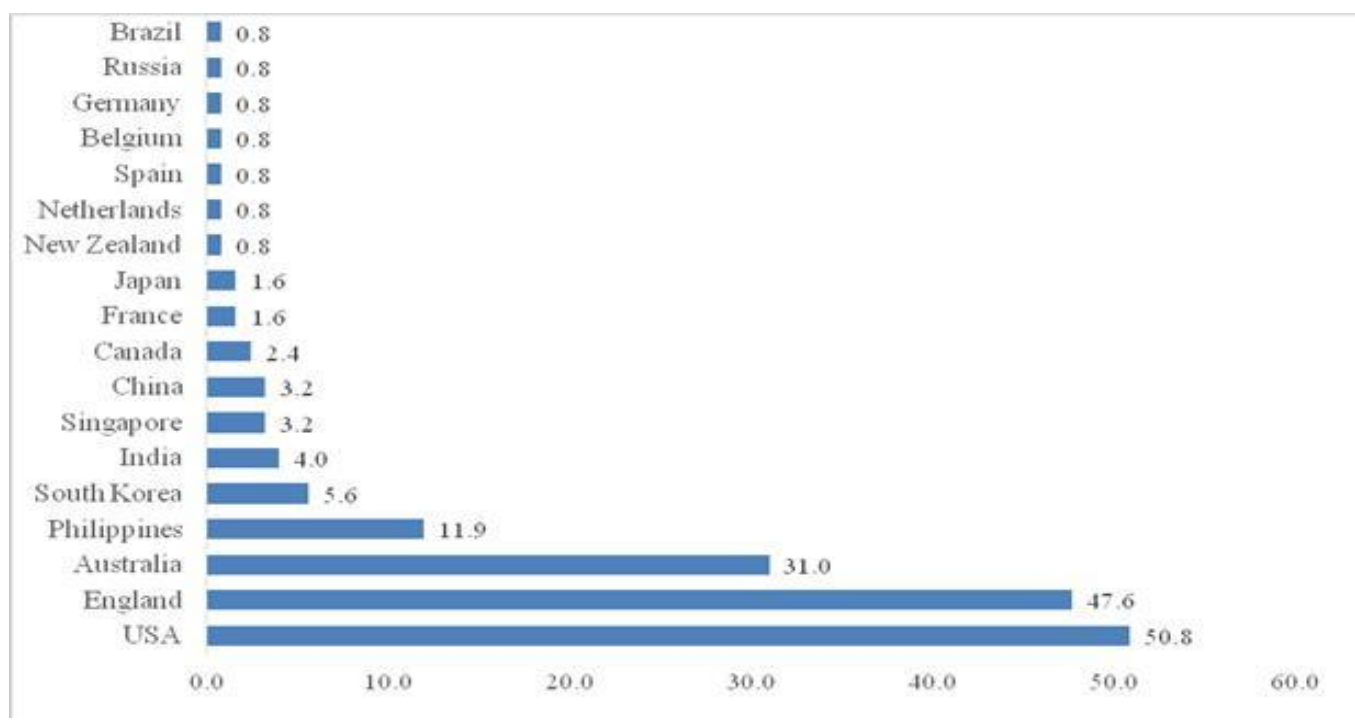

Figure 1. Percentage of students already learnt English with English speakers (\%) $(N=126)$

5.3. The subjects which students had already practiced with foreign English speakers

Students from Department of Biology had a chance to practice different skills and aspects with foreign English speakers. Speaking skill is the most popular one that students had already studied with foreign English teachers (52.4\%), next is listening skill (47.6\%). There were $36.5 \%$ of students who had a conversation with foreign English speakers. Students also studied with foreign teachers in pronunciation $(30.2 \%)$, reading $(15.1 \%)$, grammar $(11.1 \%)$ and writing (10.3\%) (Figure 2).

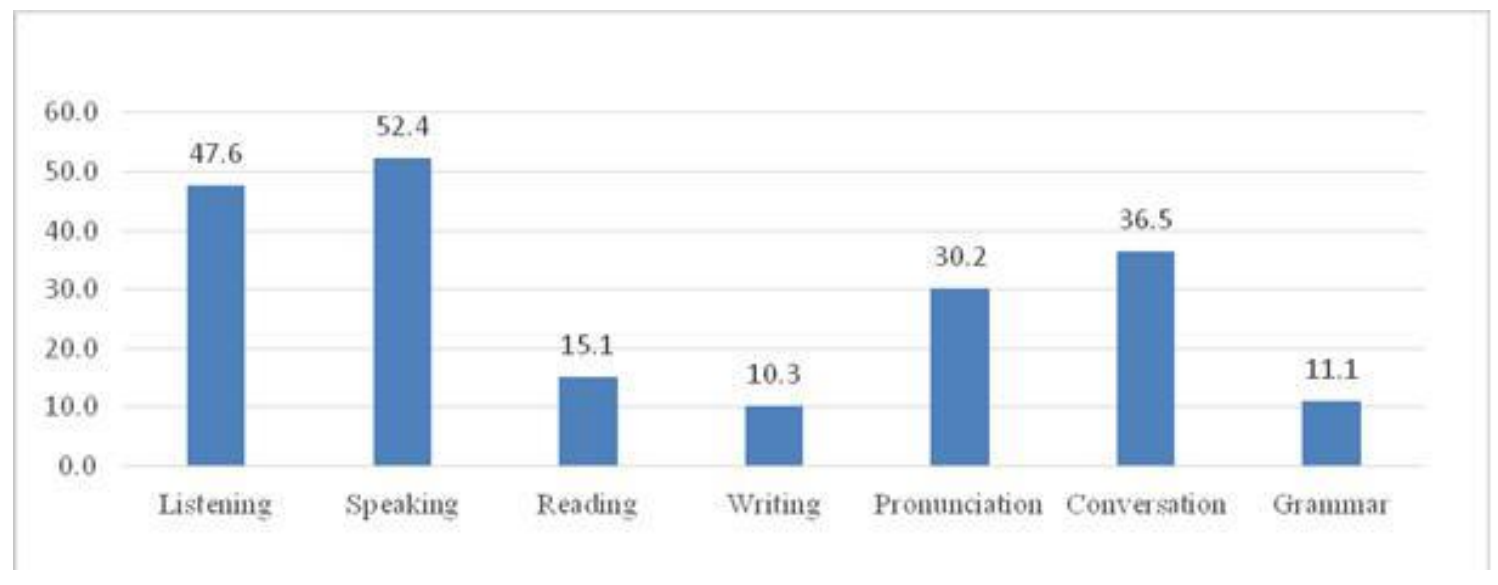

Figure 2. Percentage of English subjects which students already practiced with foreign English speakers (\%) 


\subsection{Research question 1: Students' perception of studying English for Biology with English teachers $(N=126)$}

Biological students had different opinions of learning English for Biology. Fifty-two students $(41.3 \%)$ liked studying with non-native English-speaking teachers, whereas 40 students (31.7\%) liked learning with native English-speaking teachers, and 34 students (27.0\%) preferred studying with both kinds of teachers (Table 2). The non-native English-speaking teacher in this study is Vietnamese, and the native English-speaking teachers were from England, the United States of American and Australia.

Table 2

Percentage of students liked learning English for Biology with English teachers

\begin{tabular}{|c|c|c|}
\hline & $\mathbf{N}$ & Percentage (\%) \\
\hline Students liked learning with native English-speaking teachers & $\mathbf{4 0}$ & $\mathbf{3 1 . 7}$ \\
\hline With English & 10 & 7.9 \\
\hline With American & 11 & 8.7 \\
\hline With Australian & 1 & 0.8 \\
\hline With English or American & 9 & 7.1 \\
\hline With English or Australia & 2 & 1.6 \\
\hline With American or Australia & 1 & 0.8 \\
\hline With English or American or Australia & 6 & 4.8 \\
\hline With Vietnamese and English or American & $\mathbf{5 2}$ & $\mathbf{4 1 . 3}$ \\
\hline With Vietnamese & 14 & $\mathbf{3 4}$ \\
\hline With Vietnamese and English & $\mathbf{3 4}$ & $\mathbf{2 7 . 0}$ \\
\hline Witudents liked learning with both kinds of teachers & 31.3 \\
\hline Wearning with non-native English-speaking & 5.6 \\
\hline
\end{tabular}

Source: The researcher's data analysis 
Students' perception of studying English for biology was various. For native Englishspeaking teachers, the most important perception was easy to practice pronunciation $(4.88 / 5.0$ points), the next one was easy to practice speaking (4.53/5.0 points) and easy to practice listening (4.25/5.0 points). For non-native English-speaking teachers, the highest perception was easy to practice speaking (4.38/5.00 points), easy to practice reading (4.12/5.00 points), and easy to practice writing (4.02/5.00 points). Students' perception with both kinds of teachers (native and non-native English-speaking teachers) were similar to the above results, the most important one was easy to practice speaking (4.41/5.00 points), following with easy to practice reading (4.03/5.00 points) and easy to practice listening (4.00/5.00 points). The perceptions of a good method of teaching and studying well faster were also concerned by students; however, the mean scores were lower (Table 3 ).

Table 3

Students' perceptions of studying English for Biology with English teachers

\begin{tabular}{|c|c|c|c|c|}
\hline \multirow[b]{2}{*}{ Students' perceptions } & \multicolumn{4}{|c|}{ when studying English with } \\
\hline & $\begin{array}{c}\text { all English } \\
\text { teachers } \\
(n=126)\end{array}$ & $\begin{array}{l}\text { native English- } \\
\text { speaking } \\
\text { teachers }(n=40)\end{array}$ & $\begin{array}{c}\text { non-native } \\
\text { English- } \\
\text { speaking } \\
\text { teachers } \\
(\mathrm{n}=52)\end{array}$ & $\begin{array}{c}\text { both kinds of } \\
\text { teachers } \\
(\mathbf{n}=34)\end{array}$ \\
\hline Can study well faster & $3.63 \pm 0.73$ & $3.83 \pm 0.75$ & $3.44 \pm 0.70$ & $3.68 \pm 0.73$ \\
\hline Good method of teaching & $3.46 \pm 0.74$ & $3.60 \pm 0.74$ & $3.31 \pm 0.70$ & $3.53 \pm 0.79$ \\
\hline Easy to practice listening & $3.98 \pm 0.73$ & $4.25 \pm 0.74$ & $3.75 \pm 0.68$ & $4.00 \pm 0.70$ \\
\hline Easy to practice speaking & $4.44 \pm 0.53$ & $4.53 \pm 0.55$ & $4.38 \pm 0.49$ & $4.41 \pm 0.56$ \\
\hline Easy to practice reading & $4.02 \pm 0.67$ & $3.90 \pm 0.74$ & $4.12 \pm 0.62$ & $4.03 \pm 0.67$ \\
\hline Easy to practice writing & $3.89 \pm 0.73$ & $3.88 \pm 0.76$ & $4.02 \pm 0.61$ & $3.71 \pm 0.84$ \\
\hline $\begin{array}{l}\text { Easy to practice } \\
\text { pronunciation }\end{array}$ & $4.21 \pm 0.70$ & $4.88 \pm 0.64$ & $3.96 \pm 0.68$ & $4.26 \pm 0.67$ \\
\hline
\end{tabular}

Source: The researcher's data analysis

\section{for Biology}

\subsection{Research question 2: Students' suggestions for better ways of learning English}

There were ten suggestions for good ways of learning English for Biology. According to the students, the highest one was that students should practice more often (83.3\%). The next ones related to learner autonomy and practice with foreigners with the same percentage at $43.3 \%$. The third one was also practice and it had the same percentage of watching films having subtitles in English (26.7\%). The other suggestions were listening to English songs, studying hard and so on with a lower percentage (Table 4). 


\section{Table 4}

Suggestions for good ways of learning English for Biology ( $\mathrm{N}=30)$

\begin{tabular}{|l|c|c|}
\hline \multicolumn{1}{|c|}{ Good ways of learning English for Biology } & N & $\begin{array}{c}\text { Percentage } \\
(\%)\end{array}$ \\
\hline Practice more often & 25 & 83.3 \\
\hline Learner autonomy & 13 & 43.3 \\
\hline Practice with foreigners in English & 13 & 43.3 \\
\hline Practice everyday & 8 & 26.7 \\
\hline Watching films with subtitles in English & 8 & 26.7 \\
\hline Listening to English songs & 7 & 23.3 \\
\hline Need to study hard & 6 & 20.0 \\
\hline Join English speaking club & 2 & 6.7 \\
\hline Reading English book & 2 & 6.7 \\
\hline Group work & 2 & 6.7 \\
\hline
\end{tabular}

Source: The researcher's data analysis

\section{Discussion}

Biological students in this study had chances to practice language English with English speakers from different countries, so they can show their preferences of kinds of teachers they like studying more meaningfully. Students also understood that speaking is the most important of all four skills including listening, speaking reading and writing (Ur, 2012); therefore, 52.4\% of them studied speaking skills with foreign English teachers before the research, this is the highest percentage among the other skills and aspects.

Students preferred studying English for Biology with non-native English-speaking teachers $(41.3 \%)$, Vietnamese teachers in this study, more than native English-speaking teachers or both kinds of teachers. It is very difficult to describe good teachers because different teachers often succeed in different ways (Harmer, 2010). Walkinshaw and Duong (2014) stated that learners preferred studying English with non-native English-speaking teachers because they were hard-working, good teachers of grammar, good communicators, experienced ESL learners and insightful teachers. In this study, students liked studying with them as it was easy for them to practice speaking, reading and writing. It is obvious that Vietnamese teachers had experience in studying foreign languages before so they can know what mistakes to minimize and try to use the best way to transfer knowledge to their students. This high percentage of students who chose the non-native English-speaking teachers also agreed with Cakir and Demir 
(2013), and Tosuncuoglu (2017) that learners liked them because these teachers had better grammar explanation and teaching.

For native English-speaking teachers, $31.7 \%$ of students liked studying English for Biology with them. The three high perceptions were easy to practice pronunciation, speaking and listening, and the highest one was pronunciation. This agrees with Cakir and Demir (2013) that native English-speaking teachers were better at speaking and listening. Moreover, native English-speaking teachers can have better pronunciation because they master the language they teach, have a greater self-confidence (Madrid \& Canado, 2004). Sevy-Biloon (2017), Cakir and Demir (2013), Walkinshaw and Duong (2014), and Yazawa (2017) also agreed that native English teachers had better pronunciation than non-native English-speaking teachers. These may be the reasons why students in this study liked studying with them. Walkinshaw and Duong (2012) also reported that English competence was the one which the respondents chose for the native English-speaking teacher. These findings can be considered that native English-speaking teachers for these skills were always in the higher priority in general as native teachers could speak English better than non-native counterpart and used it as a natural means of communication in class (Árva \& Medgyes, 2000; Madrid \& Canado, 2004).

Besides the students who chose either native or non-native English-speaking teachers to study English for Biology, there were $27.0 \%$ of students who would like to have both native and non-native English-speaking teachers in the same class because they thought that it was easy for them to practice speaking, reading and listening. This result is similar to the research result by Lasagabaster and Sierra (2002) that students liked studying with English-speaking teachers of the combination of both groups. These two kinds of teachers can supplement to each other because both groups had their strengths and weaknesses in English instruction. The disadvantages of this group are the advantages of the other groups in terms of the English proficiency, communication and the solution for students' problems (Tsou, 2013). Clouet (2006) also said that each teacher had different advantages and the same class should have both native and non-native teachers so that the students could get better knowledge.

Biological students considered practice was the most important one when studying English. Out of ten suggestions, three of them were practice. They said that students should practice more often (83.3\%), practice with foreigners in English (43.3\%) and practice every day (26.7\%). These agree with what Ur (2012) said that learners should actually talk a lot as much time as possible when studying English. This speaking practice should be done in the classroom first because this activity provides a rehearsal opportunity to practice real-life speaking (Harmer, 2010) and then continued outside the class. Watching films with subtitles in English was also advised to do by students (26.7\%). Desfitranita (2017) stated that some students were good at English thanks to daily practices and watching movies in English was mentioned as the best tool for language input. Another suggestion with a high percentage by students was learner autonomy (43.3\%), it means that learners need to take more responsibility for their own learning (Harmer, 2010) and posse both willingness and ability to act independently (William, 1997) to facilitate the learner to become more efficient and effective (Najeeb, 2013).

\section{Conclusion}

Students in the Department of Biology have different opinions of learning English for Biology. Fifty-two students (41.3\%) liked studying with non-native English-speaking teachers, whereas 40 students (31.7\%) liked learning with native English-speaking teachers, and 34 students $(27.0 \%)$ preferred studying with both kinds of teachers. Students also suggested some 
ways to improve the learning effectiveness including regular practice, learner autonomy, practice with foreigners, and so on. The research result will help the Dean take into consideration the importance of teachers in teaching and learning English for Biology in Department of Biology.

\section{References}

Albakrawi, H. T. M. (2014). Is there a difference between native and non-native English teachers in teaching English? Journal of Scientific Research and Studies, 1(6), 87-94.

Alseweed, M. A. (2012). University students' perceptions of the influence of native and nonnative teachers. English Language Teaching, 5(12), 42-53.

Árva, V., \& Medgyes, P. (2000). Natives and non-natives teachers in the classroom. System, 28(3), 355-372.

Cakir, H., \& Demir, Y. (2013). A comparative analysis between NESTs and NNESTs based on perceptions of students in preparation classes. The International Journal of Social Sciences, 14(1), 36-47.

Clouet, R. (2006). Native vs. non-native teachers: A matter to think over. Revista de Filologia, $24,69-75$.

Desfitranita, D. (2017). Students' rules and practices: How to speak English fluently? Al-Ta 'lim Journal, 24(1), 19-28. doi:10.15548/jt.v24i1.253

Fraenkel, J. R., \& Wallen, N. E. (2009). How to design and evaluate research in education. New York, NY: McGraw-Hill Companies.

Harmer, J. (2010). How to teach English. Oxford, UK: Pearson education limited.

Lasagabaster, D., \& Sierra, J. M. (2002). University students' perceptions of native and nonnative speaker teachers of English. Language Awareness, 11(2), 132-142.

Luk, J. C. M., \& Lin, A. M. Y. (2007). Classroom interactions as cross-cultural encounters: Native speakers in EFL lessons. Mahwah, NJ: Erlbaum.

Ma, L. P. F. (2012). Perceived teaching behaviour of native and non-native English-speaking teachers in Hong Kong: Are there any differences? Hong Kong Journal of Applied Linguistics, 14(1), 89-108.

Madrid, D., \& Canado, M. L. P. (2004). Teacher and student preferences of native and nonnative foreign English teachers. Porta Linguarum, 2, 125-138.

Medgyes, P. (1994). The Non-native teacher. London, UK: MacMillan Publishers.

Najeeb, S. S. R. (2013). Learner autonomy in language learning. Procedia - Social and Behavioral Sciences, 70, 1238-1242.

Pham, T. C., \& Huynh, H. C. M. (2018). Students' perception of the advantages and disadvantages of studying pronunciation and speaking with foreign teachers. Proceedings: Open TESOL - The sixth international open TESOL conference 
proceedings 2018 - Language learning and teaching transformation in the post - method era, 295-310.

Rechardson, S. (2016). Plenary: The "native factor": The haves and the have-nots... and why we still need to talk about this in 2016. In T. Pattison (Ed.), IATEFL 2016 Birmingham conference selections (pp. 79-89). Faversham, UK: IATEFL.

Sevy-Biloon, J. (2017). Educators and students perceptions about Ecuadorian NEST knowledge and quality in terms of effective teaching. The Southeast Asian Journal of English Language Studies, 23(3), 123-132.

Tosuncuoglu, I. (2017). Non-native \& native English teachers. Journal of History Culture and Art Research, 6(6), 634-638.

Tsou, S.-Y. (2013). Taiwanese University students' perception toward native and non-native English-speaking teachers in EFL contexts (Doctoral dissertation, College of Graduate Studies Texas A \& M University - Kingsville, Texas,). Retrieved from October 20, 2017, from http://ir.lib.kuas.edu.tw/bitstream/987654321/13094/2/Taiwanese_university_students_ perceptions_toward_native_and_nonnative_Englishspeaking_teachers_in_EFL_context s.pdf

Ur, P. (2012). A course in English language teaching. Cambridge, UK: Cambridge University Press.

Walkinshaw, I., \& Duong, T. H. O. (2012). Native and non-native speaking English teachers in Vietnam: Weighing the benefits. The Electronic Journal for English as a Second Language, 16(3), 1-16.

Walkinshaw, I., \& Duong, T. H. O. (2014). Native and non-native English language teachers: Student perceptions in Vietnam and Japan. SAGE Journals, 4(2). doi: $10.1177 / 2158244014534451$

William, L. (1997). Self-assess: Why do we want it and what can it do? In P. Benson \& P. Voller (Eds.), Autonomy and independence in language learning (pp. 79-91). Harlow, UK: Longman.

Xiaoru, C. (2008). A survey: Chinese college students' perception of non-native English teachers. CELEA Journal (Bimonthly), 31(3), 75-82.

Yazawa, O. (2017). Students' perception of native English-speaking teachers and Japanese teachers of English: The effect on students' self-efficacy and emotional state. Eruditi, $1(3), 61-72$. 